\title{
24
}

\section{The evolution of a coastal peatland at Byron Bay, Australia: Multi-proxy evidence from the microfossil record}

\author{
Kathryn H. Taffs
}

School of Environmental Science and Management, Southern Cross University, Lismore, NSW, Australia kathryn.taffs@scu.edu.au

\section{Brendan Logan}

School of Environmental Science and Management, Southern Cross University, Lismore, NSW, Australia

\section{Jeff F. Parr}

School of Environmental Science and Management, Southern Cross University, Lismore, NSW, Australia

\section{Geraldine E. Jacobsen}

Australian Nuclear Science and Technology Organisation, Lucas Heights, Sydney, NSW, Australia

\section{Introduction}

Peatlands are highly valuable ecosystems for their ecological functions as well as their economic and societal values (Charman 2002). Yet they are also highly vulnerable to degradation by a range of anthropogenic activities and climate change (Charman 2002; Gorham and Rochefort 2003; O'Connell 2003; Rochefort et al. 2003; Vasander et al. 2003). In Australia, peatlands are an unusual and infrequent component of the landscape (Whinam et al. 2003), mostly distributed in the alpine areas of the southeast of the continent (Clarke and Martin 1999). However, areas of peat also occur in the coastal lowlands, often in dune swales, both on the east coast of Australia and on the southwest coast of Western Australia (Whinam et al. 2003). Coastal peatlands are unique environments and can be very informative about environmental and sea-level change in the coastal zone. Peat deposits in coastal areas of the Northern Hemisphere have provided informative records of water-level changes, which in turn can be used to complement existing palaeoclimatic and sea-level reconstructions (e.g. Eronen et al. 1987; Denys 1989; Campeau et al. 2000; Finkelstein and Davis 2005). At present, there is a lack of research focusing on Australian coastal peatlands. A deeper 
understanding of the response of coastal areas to climatic and anthropogenic influences is required to maximise conservation efforts of these unique environments.

Coastal peat formation is induced by waterlogging of silted-up areas when there is sufficient supply of freshwater (Kumano et al. 1990). In eastern Australia, many coastal peatlands occur naturally as thin strips behind the barrier dune systems. Australian coastal peatlands are dominated by Restionaceae, Cyperaceae and Epacridaceae vegetation (Whinan et al. 2003). They were generally formed in the past 4000 to 6000 years, since the last high-sea-level stand (Lewis et al. 2008). However, they have been heavily impacted by anthropogenic activities in the densely populated, resource-rich, coastal zone (Taffs et al. 2006). As a result, many coastal peatlands have been extensively damaged and/or removed by agriculture and urbanisation land uses.

Peatland conservation is Australia is very ad hoc and mostly aims to conserve representative portions of different peatland types (Whinan et al. 2003). Yet coastal peatlands are underrepresented compared with other peatland types because of their location within the densely populated coastal zone. Developing a full understanding of the pre-anthropogenic impacts and natural variability of coastal peatlands is required to improve their management and conservation. Palaeoecological techniques provide ideal tools to identify natural benchmark conditions and variability such as vegetational change and response to anthropogenic impacts (Gaiser and Ruhland 2010). This provides essential information for managers of peatland systems to maximise their conservation.

Plant macrofossils such as phytoliths (e.g. Lewis 1981; Piperno 1988; Carter 1998; Kealhofer and Penny 1998; Parr 2003; Taffs et al. 2006) and pollen (e.g. von Post 1916; Godwin 1940; Wein et al. 1987; Gignac et al. 1991; Jasinski et al. 1998) are the traditionally used microfossils in peatland palaeoecological studies. They provide important information on vegetation composition and change over time. Phytoliths and pollen complement each other in a number of ways. Firstly, due to its airborne nature, pollen provides an indicator of regional vegetation changes, while phytoliths are for the most part deposited in situ and are useful for examining changes in vegetation at a specific site. Secondly, not all plants are prolific producers of phytoliths and/or pollen, and thus using both of these microfossils for palaeoecological reconstruction provides the best opportunity to identify a broad range of vegetation types (Kealhofer and Penny 1998; Taffs et al. 2006).

In coastal peatlands, the changing interface between the marine and terrestrial landscape strongly influences peatland water levels and water quality (Freund et al. 2004). Diatoms are regarded as very sensitive indicators of changes in water quality (Stoermer and Smol 1999) and are useful tools to describe palaeoenvironmental conditions in humiferous as well as in clastic lithofacies, such as those that accumulate in coastal lagoons. However, comprehensive studies of diatom flora from peatland systems remain scarce (Pienitz 2001; Gaiser and Ruhland 2010).

While peats are useful archives of environmental information, they are difficult environments in which to study siliceous microfossils such as diatoms and phytoliths (Bennett et al. 1991). Biogenic silica cycling causes breakdown of siliceous materials in anoxic, organic-rich, neutral-pH environments that are typical of coastal peatlands (Bennett et al. 1991). The fragility of diatom frustules makes them particularly susceptible to degradation and breakdown. Yet diatom dissolution data can aid interpretation of sedimentary profiles as records of limnological, ecological and environmental change (Ryves et al. 2009).

There are some coastal peatland sites that have sufficiently well-preserved siliceous microfossils to identify environmental change. These include the Beaufort Sea (Campeau et al. 2000), the western Belgian coast (Denys 1989), the western coastline of the United States and Canada (Eronen et al. 1987), the Lower Saxony, Germany (Freund et al. 2004), and the coastal plains of Japan (Kumano et al. 1990). In some of these studies, diatom dissolution 
occurred to the extent that full counts of each sample could not always be obtained (Eronen et al. 1987; Denys 1989; Campeau et al. 2000). Yet the extent of dissolution or fragmentation was used to aid environmental interpretation.

Given the strengths and weaknesses of any given environmental indicator on its own, the advantages of using multiple proxy indicators have been underscored in numerous peatland palaeoecological papers (e.g. Korhola 1990; Jaskinski et al. 1998; Rühland et al. 2000, 2006; Langdon et al. 2003; Blundell and Barber 2005; Myers-Smith et al. 2008). The aim of this paper is to examine the preservation of siliceous microfossils (diatoms and phytoliths) in a coastal peatland in eastern Australia and determine the environmental history that these fossils are able to reveal in combination with pollen, lithological and chronological information. A more detailed understanding of the evolution of this coastal plain and the response of the ecosystem to anthropogenic impacts is a priority to inform management strategies for the region's coastal peatlands.

\section{Study area}

Byron Bay (Figure 1) is located on the northern coast of New South Wales, Australia. It is a quartz-dominated sand province that has had its geomorphology shaped by pre-Holocene estuarine sediment deposits, the onshore movement of sands which accompanied the Holocene sea-level rise, and the reworking of coastal deposits by wind, wave and current actions after sea levels stabilised around $6000 \mathrm{yr}$ BP (Chapman et al. 1982). The adjacent Belongil estuary has developed as a result of tidal forces in the relatively short time available during the Holocene for the estuary to infill under a steady sea level (Harris et al. 2002).
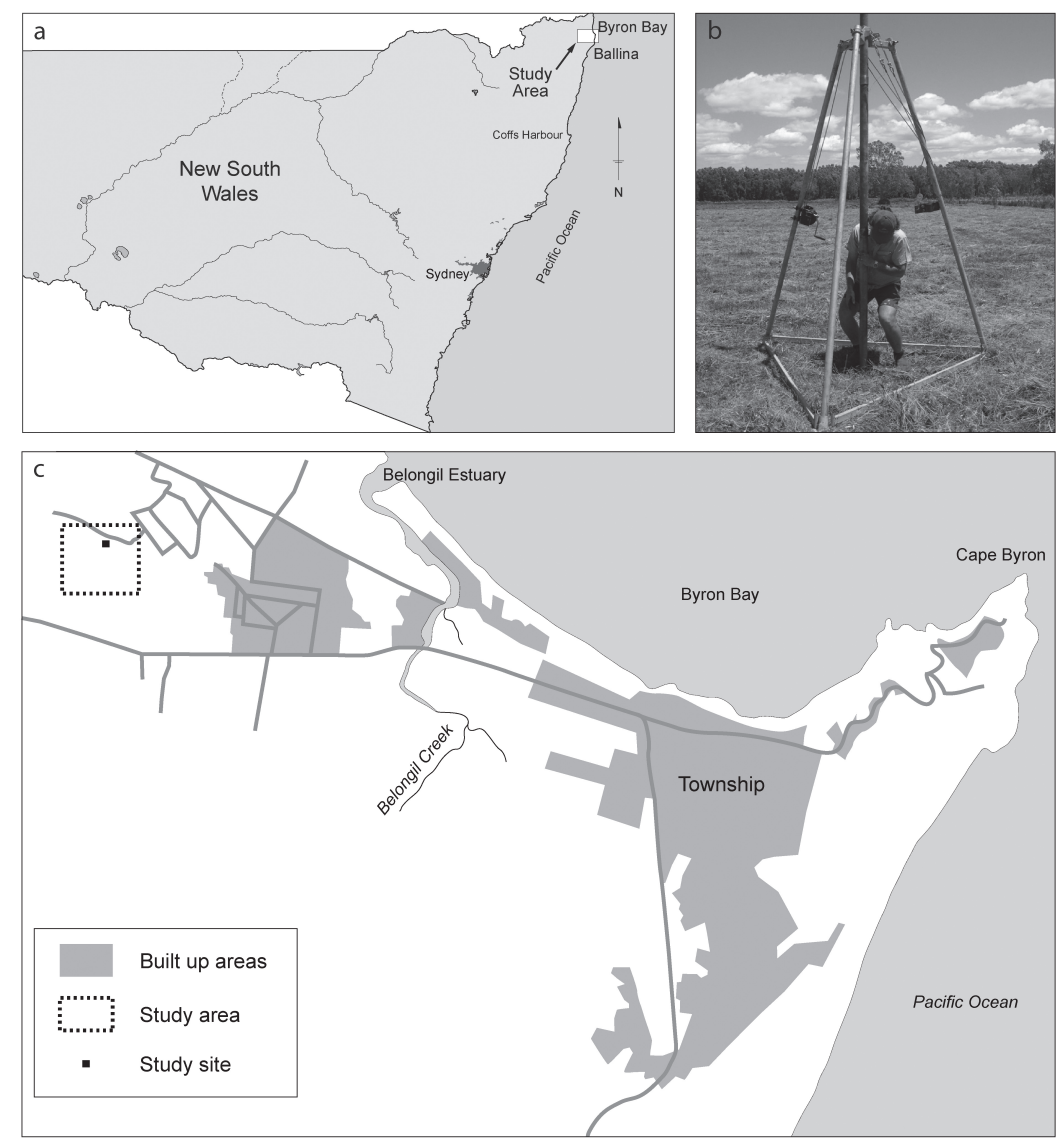

Figure 1. Location of Byron Bay: (a) location of Byron Bay within New South Wales, Australia; (b) photo of the site where the sediment core was extracted; (c) location of the sediment core extraction site 
The site used for this study is $2.6 \mathrm{~m}$ asl (Byron Shire Council 2003). It is a 24 ha wetland located in the Belongil Swamp, which is a back barrier swamp on an estuarine/alluvial plain, bordered by bedrock hills to the west, and by a series of up to 13 Pleistocene beach ridges with an elevation of 5-6 m to the east (Geomarine 1997). The swamp is connected to an intermittently open estuary, Belongil Creek, via artificial drains. The Belongil Creek catchment drains an area of approximately 2840 ha (Geomarine 1997). The wetland is dominated by peat, and is bordered with Melaleuca quinquinervia and Blechnum indicum dominated vegetation. The surrounding area also contains significant proportions of dry sclerophyll, sedgeland and littoral rainforest associations.

\section{Methods}

In 2003, three sediment cores were extracted along a transect that incorporated the major depositional environments of a coastal peatland complex near Byron Bay (28 38' 00" S, 135 34 ' 25” E). We present here the results of analysis of a $5.2 \mathrm{~m}$ long sediment core retrieved in $1.5 \mathrm{~m}$ sections using a Vibracorer. Results of the two smaller sediment cores were reported in Taffs et al. (2006). The sediment-core sections were split vertically, with one half frozen for lithological analyses (sediment grain size, loss on ignition and pyrite content) and the other half sub-sampled for microfossil analysis (pollen, phytoliths and diatoms). In addition, pollen was extracted from sediment samples for AMS ${ }^{14} \mathrm{C}$ analysis using the analytical facilities of the Australian Nuclear Science and Technology Organisation (ANSTO).

Organic content was determined according to the loss-on-ignition method of Bengsston and Enell (1986) to characterise the sediment. Samples were oven-dried then ignited in a muffle furnace at $550^{\circ} \mathrm{C}$ for two hours. After cooling within a dessicator, samples were weighed and the lost material expressed as a percentage of dry weight.

The reduced inorganic sulfur fraction (which includes pyrite and other iron disulfides, elemental sulfur, and acid volatile sulfides) was measured in duplicate on 20 samples using the chromium reducible sulfur technique of Sullivan et al. (2000) in order to provide a measure of pyrite content of the sediments. After peroxide oxidation, all residues were washed three times with distilled water, centrifuged, and oven-dried at $60^{\circ} \mathrm{C}$ before chromium reducible sulfur analysis. Pyrite can indicate the prevalence of a reducing environment occurring under anoxic conditions during deposition (Bajpai et al. 2001). Thus, the occurrence of pyrite in sedimentary sequences indicates marine origins and can have significant palaeoenvironmental value.

Diatom samples were processed according to the method of Parr et al. (2004), and were inspected under an Olympus CX40 compound light microscope fitted with an Olympus DP10 digital camera at 1000X magnification. A minimum of 300 diatom frustules were identified and counted from each sample to determine the diatom assemblage where possible. The diatoms were identified using the photographs of Foged (1978) and Gell et al. (1999). Only species that had a relative abundance greater than $2 \%$ were included in the data set. For rapid assessment of diatom preservation, the method of Dong et al. (2008) was adopted. This method estimates diatom preservation in three categories: (1) slides with good diatom preservation (the assemblages are almost pristine with the whole community preserved well without signs of dissolution and fragmentation); (2) medium fragmentation (assemblages partially dissolved but with most species well preserved); and (3) poor preservation (most species dissolved, only robust species remaining).

Phytoliths were extracted from sediment using the method of Parr (2002). Phytoliths extracted from each sample were weighed, mounted on to microscope slides and scanned at 400x magnification on an Olympus BH2 microscope. A total of 150 diagnostic phytolith types were counted for each slide. A collection of plant species was made in and around the study site and phytoliths extracted using the method of Parr et al. (2001) for use in a comparative 
database. Identification of phytoliths was based on a probability method (Parr 2004), in which fossil phytolith morphotypes were compared with those represented in a regionally specific phytolith database; the more commonly a plant taxon is represented by different morphotypes, the more likely it is considered that the taxon in the database is represented.

Pollen was extracted from $1 \mathrm{cu} . \mathrm{cm}$ of sediment using the method described in Cotter and Boyd (1998), excluding the hydrofluoric acid treatment that was considered unnecessary due to the low silica content of the sediment. Pollen extracted from each sample was mounted on to microscope slides and scanned at 600x and 1000x magnification on an Olympus BH2 microscope. A total pollen sum of 500 grains was counted per sample.

Ten samples were prepared for AMS ${ }^{14} \mathrm{C}$ dating using the pollen fraction. These were processed and measured at the Australian Nuclear Science and Technology Organisation (ANSTO, sample numbers OZH042 to OZH051, Fink et al. 2004). Radiocarbon dates were calibrated using CALIIB 5.0 (Stuiver and Reimer 1993). Dates less than 11 ka were calibrated using the Southern Hemisphere radiocarbon calibration data set ShCal04 (McCormac et al. 2004). Dates 11-26 ka were calibrated using the international radiocarbon calibration data set IntCal04 (Reimer et al. 2004), while dates older than $26 \mathrm{ka}$ are uncalibrated (Reimer et al. 2004).

All results were graphed using the package C2 (Juggins 2004) and displayed using a stratigraphic diagram. Biostratigraphic zones were established, based on the distinct lithological sequence observed in the sediment core.

\section{Results}

\section{Chronology}

Table 1 shows the AMS ${ }^{14} \mathrm{C}$ results with radiocarbon and calibrated ages. Radiocarbon ages ranged from $4300 \pm 50$ at 50-55 cm depth to $41,800 \pm 1200$ at 510-515 cm depth. Figure 2 shows the age-depth model for the sediment core and the core lithology. The basal material is fine, muddy sand, extending from $520 \mathrm{~cm}$ to $300 \mathrm{~cm}$ and corresponds to an uncalibrated radiocarbon age of $\sim 42,000 \mathrm{yr} \mathrm{BP}$ to $-33,000 \mathrm{yr} \mathrm{BP}$. A sand layer was deposited $-33,000 \mathrm{yr}$ BP, which grades back into sandy mud from $260 \mathrm{~cm}$ to $130 \mathrm{~cm}$, or $-33,000 \mathrm{yr}$ BP to 9000 $9396 \mathrm{cal}$. yr BP. There is a small horizon representing a distinct colour change at 170-175 $\mathrm{cm}$, that is 10,309-10,763 cal. yr BP. The Sandy Mud and Muddy Sand sediments are typical of Pleistocene estuarine deposits on the north-coast coastal plain (McGrath and Boyd 1998; Taffs et al. 2008). The upper peat deposit is $130 \mathrm{~cm}$ deep and extends from approximately 5327-5709 cal. yr BP to the present.

Table 1. Radiocarbon ages from the Byron Bay sediment core

\begin{tabular}{|l|l|l|l|l|}
\hline Laboratory No. $^{\mathbf{a}}$ & Core depth $\mathbf{( c m )}$ & Radiocarbon age $(\mathbf{y r}$ BP) & Calibrated age $\left(\mathbf{c a l} \mathbf{y r}\right.$ BP) $^{\mathbf{b}}$ & Dated material \\
\hline OZH042 & $50-55$ & $4300 \pm 50$ & $4581-4959$ & pollen \\
\hline OZH043 & $120-125$ & $4880 \pm 60$ & $5327-5709$ & pollen \\
\hline OZH044 & $140-145$ & $8240 \pm 60$ & $9000-9396$ & pollen \\
\hline OZH045 & $160-165$ & $9430 \pm 60$ & $10304-10763$ & pollen \\
\hline OZH046 & $170-175$ & $15,110 \pm 110$ & $18062-18713$ & pollen \\
\hline OZH047 & $190-195$ & $15,480 \pm 100$ & $18647-18936$ & pollen \\
\hline OZH048 & $250-255$ & $33,530 \pm 320$ & & pollen \\
\hline OZH049 & $310-315$ & $33,050 \pm 300$ & & pollen \\
\hline OZH050 & $410-415$ & $42,900 \pm 1600$ & & pollen \\
\hline OZH051 & $510-515$ & $41,800 \pm 1200$ & & pollen \\
\hline
\end{tabular}

a. Australian Nuclear Science and Technology Organisation (ANSTO) laboratory code.

b. Calibrated using program CALIB 5.0, reported using the 2 sigma range. 


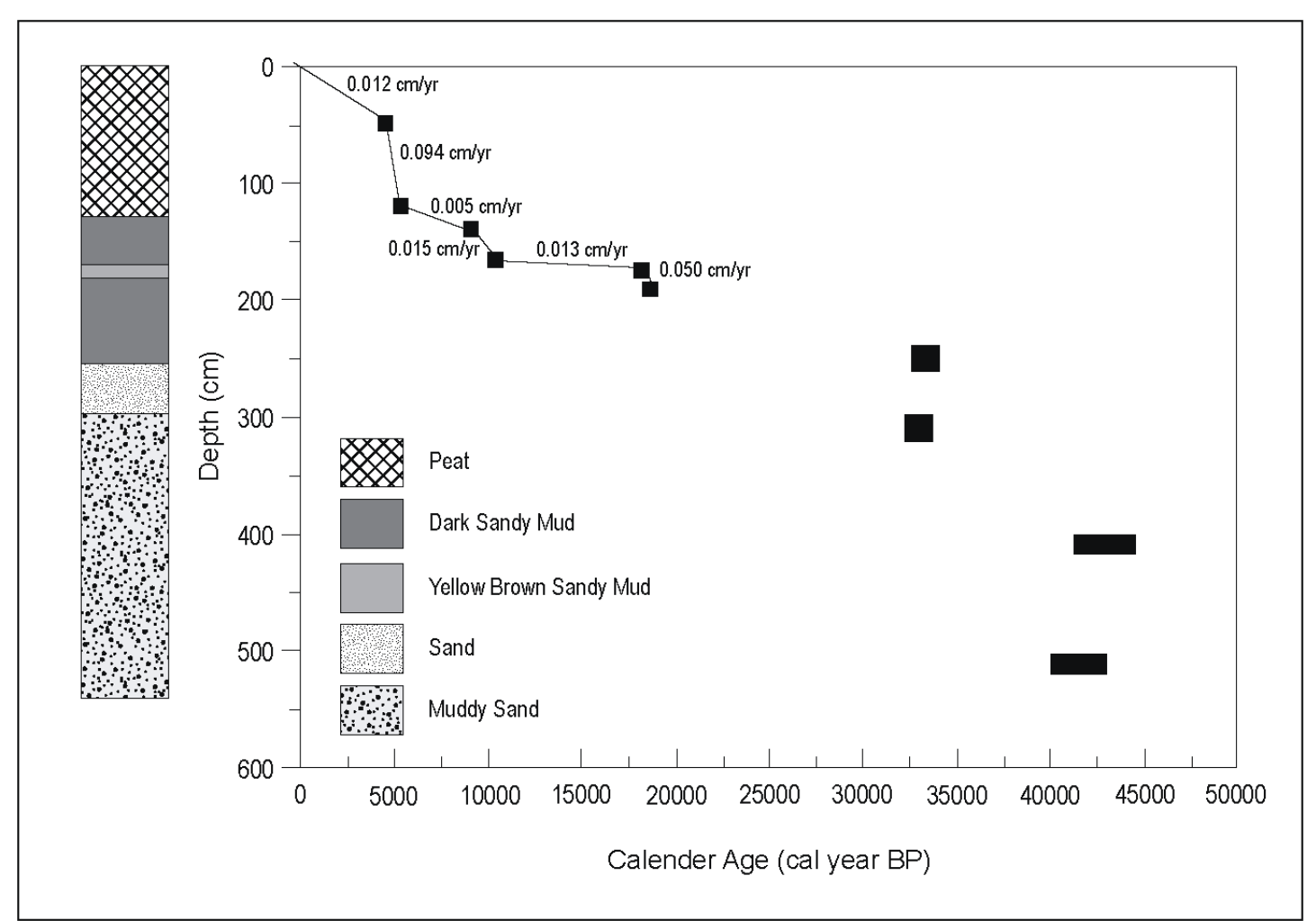

Figure 2. Age-depth curve of the Byron Bay sediment core. Note samples $>26$ ka have not been calibrated and hence sedimentation rate for this portion of the core has not been calculated

Sedimentation rates are very low throughout the core. Accumulation rates have not been calculated for the basal estuarine muddy-sand substrates as the dates are not able to be calibrated accurately and hence compared with the calibrated dates of the upper sediments. The upper Sandy Mud layer has a very low average accumulation rate of $0.018 \mathrm{~cm} / \mathrm{yr}$ (range $0.0013-0.05 \mathrm{~cm} / \mathrm{yr}$ ). The accumulation of the peat layer reduces considerably towards the surface, with a sedimentation rate of $0.094 \mathrm{~cm} / \mathrm{yr}$ for the lower section of the peat and 0.012 $\mathrm{cm} / \mathrm{yr}$ for the upper section of peat. The general stratigraphic consistency within the core and the gradual boundaries between sediment layers suggest continuous sediment accumulation with only minor reworking of the sediments between boundaries.

\section{Diatoms}

Diatom preservation deteriorated with increasing depth in the core (Figure 3). Diatoms were abundant and well preserved in the surface peat. However, there were no diatoms present in zone 3 , in the sand layer, and diatom preservation was very poor in zone 4, with only frustles of the most robust species, Nitzschia fonticola, present. Only six diatom species occurred in the sediment core with a relative abundance of $>2 \%$, representing a very low diversity. The dominant genera were Nitzschia, Eunotia and Pinnularia. Nitzschia fonticola was dominant throughout the core. This species is known to be quite cosmopolitan and in some coastal sites widespread and abundant (Foged 1978; Vyverman et al. 1995). Nitzschia paleaeformis was present only in the surface peats, suggesting a change in the depositional environment occurred around 5000 cal. yr BP, marking the commencement of peat formation. Eunotia soleroii, Eunotia flexuosa and Pinnularia gibba were found throughout zone 1 and 2, suggesting a continuously acidic habitat (Sterrenburg et al. 2007). Pyrite, also displayed in Figure 3, was present throughout the core but was detected at very high levels within zone 4, indicating marine conditions were prevalent during deposition of these sediments. The organic content was high throughout the surface peat and in zone 2, negligible in zone 3 and a minor component in zone 4 . 


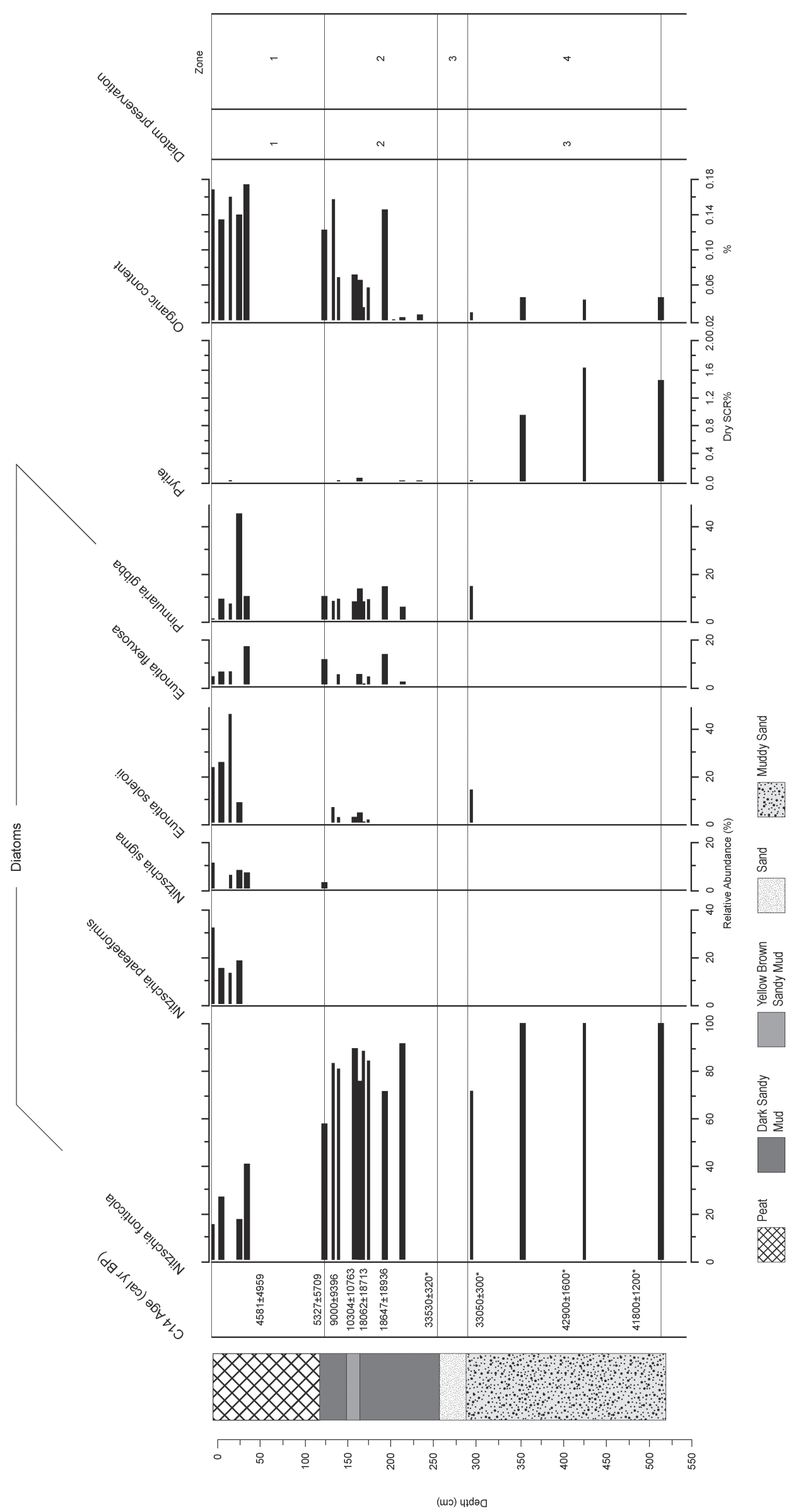

Figure 3. Diatom record of the coastal peat sediment core from Byron Bay. Radiocarbon ages > 26 ka have not been calibrated 


\section{Phytoliths and pollen}

The phytolith record (Figure 4) indicates the vegetation surrounding the site has been a grassland fringed with Melaleuca forest for the past $-33,500 \mathrm{yr}$ BP. The understorey is dominated by Poaceae, Restionaceae and Cyperaceae species. The tree component was dominated by Myrtaceae Melaleuca species type, possibly indicating a single-species tree component of the vegetation community. The tree component is significant in the lower sections of the core until 4581-4959 cal. yr BP, after which it reduces considerably until relatively recently. In the more recent sediments, there are low counts of Myrtaceae phytolith types. The understorey of shrub and grass species dominates the vegetation, forming $80-90 \%$ of the vegetation mass throughout the period of peat deposition. Restionaceae and Cyperaceae are peat-forming vegetation types and their abundance increases within the peat litological zones.

The pollen record provides further evidence of a grassland community with fringing Melaleuca forests within the catchment area. The tree component is dominated by Myrtaceae Melaleuca type and Casuarinaceae. Cyantheaceae is a dominant understorey shrub, most likely on the margins of the peatland. The pollen data suggest that herbaceous taxa have been the dominant vegetation component of this peat environment for the past $-33,000 \mathrm{yr}$ BP. The upperstorey component is minor but shows distinct fluctuations over time.

\section{Discussion}

The coastal peat layer at Byron Bay is $130 \mathrm{~cm}$ deep and has accumulated over the past 5000 cal. yr BP, demonstrating a very slow accumulation rate typical of peatlands (Charman 2002). The presence of peat of this age in such close proximity to the ocean indicates that sea levels stabilised in this area approximately $5000 \mathrm{cal}$. yr BP and the peatland has since been infilling with terrestrially derived sediment. Underlying the peat are sediments of estuarine origin with fine mud particles and very low organic component, indicating higher sea levels in the period preceding $5000 \mathrm{cal}$. yr BP. The presence of pyrite in these sedimentary layers confirms a strong marine influence on the sediments deposited during this time (Bajpai et al. 2001). This correlates with evidence from Larcombe et al. (1995) and Lewis et al. (2008) on eastern-Australian sea-level fluctuations. The distinct colour change of the estuarine muds at $10,300 \mathrm{cal}$. yr BP suggests a fluctuation of sea level at this time and a change in sediment origin. Stronger marine influence as indicated by the deposition of sand around 33,000 yr $\mathrm{BP}$ indicates a slight increase of sea level or change in coastal geomorphology and hence the proximity of Belongil estuary. However, before this time, up to 42,000 $\mathrm{yr} \mathrm{BP}$, the site experienced stable estuarine conditions.

Unfortunately, the diatom record has not contributed significant evidence for the reconstruction of environmental conditions of the coastal plain due to degradation of the silica frustules. Even in the surface peats, only six species were present, indicating very low species diversity. This is typical of peats with their harsh acidic environment (Sterrenburg et al. 2007). However, even six species is a very low diversity for a peatland (Campeau et al. 2000). The species present do indicate acidic freshwater environments (Foged 1978; Vyverman et al. 1995). The introduction of Nitzschia paleaeformis when peat accumulation commences is indicative of a change of trophic status that would be expected with the commencement of the accumulation of organic matter.

The diatom record does show a gradual deterioration in the preservation of frustules with increasing depth. This does indicate that diatoms were present at the time of sediment deposition but silica cycling has caused gradual deterioration of frustules present. This is typical of both peat and marine environments. With the two processes occurring at the one location due to both the acid environment of the peat and the saline marine origins, this deterioration 


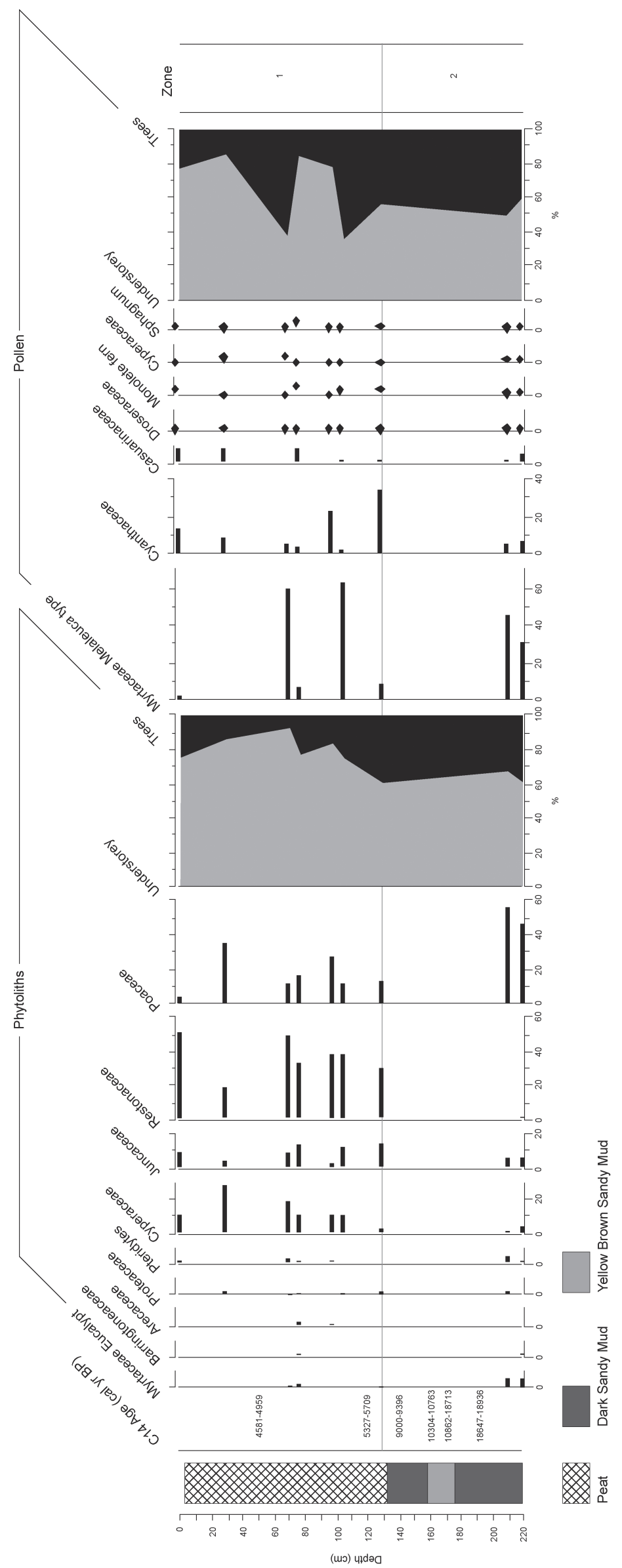

Figure 4. Phytolith and pollen record of the coastal peat sediment core from Byron Bay 
is not surprising (Lewin 1960; Bennett et al. 1991). Clearly, more robust species were better preserved and had a higher relative abundance in the sediment core.

In contrast, the phytoliths were well preserved in the peat layer. Phytoliths are very robust silica structures and less prone to deterioration than diatoms (Parr and Sullivan 2005). Comparison of the phytolith and pollen record indicates the strength of using the two indicators together, with the phytolith record indicating the local site vegetation characteristics and the pollen record reflecting vegetation composition changes within the catchment area. Both indicators show varying levels of dominance of the understorey vegetation over the period of peat accumulation. Throughout the past $5000 \mathrm{cal}$. yr BP, the peatland has been a grassland surrounded by Melaleuca forest. The dominant peat-forming vegetation is Restionaceae and Cyperaceae species, which is typical of Australian coastal peatlands (Whinan et al. 2003).

\section{Conclusion}

This palaeoecological study found no detectable evidence of sea-level change for the past 5000 cal. yr BP, which indicates that sea levels have possibly been relatively stable on the coastal plain adjacent to Byron Bay during this period, allowing terrestrial processes to dominate and the accumulation of peat to occur. Before this time, the sea level was slightly higher than at present, and the site was shaped by estuarine processes, as evidenced by the constant deposition of estuarine muds. There was a period of very strong marine influence around 33,000 yr BP, which indicates either higher sea levels or a change in the proximity of the Belongil estuary to the core location. This period of estuarine dominance continues until at least 42,000 yr BP.

During the period of peat accumulation, the vegetation was dominated by grassland, with Restionaceae and Cyperaceae being the dominant peat-forming vegetation. The grassland was surrounded by Melaleuca forest that contributed significantly to the regional pollen record. Throughout the period of peat deposition, the quality of the interstitial water was freshwater and acidic. These conditions are not conducive to the preservation of diatom frustules and hence the diatom record showed deteriorating preservation throughout the core. This is especially so in the estuarine-influenced section of the core and is typical of marine deposits (Lewin 1960; Dixet et al. 2001).

This study indicated that a multi-proxy methodology in a peatland environment has been able to provide insightful information on the development of a coastal peatland. In combination with an excellent dating record, diatom, phytolith, pollen and lithological changes have contributed to a better understanding of the development of the peatland, and baseline information has been ascertained from which more effective conservation and management decisions can be made.

\section{Acknowledgements}

Funds for the project were provided by a Southern Cross University Internal Research grant. The AMS ${ }^{14} \mathrm{C}$ dating was made possible by an Australian Institute of Nuclear Science and Engineering (AINSE) grant to Taffs (04/150). Many thanks to Steve Abbott for assistance with field work and Keith Bolton for development of site understanding. 


\section{References}

Bajpai, U., M. Kumar, M. Shukla, A. Prakash and G.P. Srivastava 2001. Nature and composition of pyrite framboids and organic substrate from degraded leaf cuticles of Late Tertiary sediments, Mahuadanr Valley, Palamu, Bihar. Current Science 81:102-106.

Bengsston, L. and M. Enell 1986. Chemical Analysis. In B.E. Berglund (ed) Handbook of Holocene Paleoecology and Paleohydrology, pp423-454. New Jersey: Blackburn Press.

Bennett, P.C., D.I. Siegel, B.M. Hill, and P.H. Glaser 1991. Fate of silicate minerals in a peat bog. Geology 19:328-331.

Blundell, A. and K. Barber 2005. A 2800-year palaeoclimatic record from Tore Hill Moss, Strathspey Scotland: the need for a multi-proxy approach to peat-based climate reconstructions. Quaternary Science Reviews 24:1261-1277.

Byron Shire Council 2003. Byron Shire Council Mean Sea Level Data. Byron Bay, NSW.

Campeau, S., A. Héquette and R. Pienitz 2000. Late Holocene diatom biostratigraphy and sealevel changes in the southeastern Beaufort Sea. Canadian Journal of Earth Sciences 37:63-80.

Carter, J.A. 1998. Palaeoenvironmental reconstruction from the last interglacial using phytolith analysis, southeastern North Island, New Zealand. In D.M. Hart, G.S. Humphreys and R.J. Field (eds) p46. Australasian Phytolith Workshop. Sydney: Macquarie University.

Chapman, D.M., M. Geary, P.S. Roy and B.G. Thom 1982. Coastal evolution and coastal erosion in New South Wales. Darlinghurst, Sydney: David Ell Press.

Charman, D. 2002. Peatlands and Environmental Change. Chichester: John Wiley and Sons.

Clarke, P.J. and A.R.H. Martin 1999. Sphagnum Peatlands of Kosciuzko in relation to altitude, time and disturbance. Australian Journal of Botany 47:519-536.

Cotter, M.M. and W.E. Boyd 1998. Fossilpollen extraction forpalaeoenvironmental reconstruction. A method manual. Lismore, Australia: School of Resource Science and Management, Southern Cross University.

Denys, L. 1989. The transition from Calais deposits to surface peat in the western Belgian coastal plain. Results of a paleo-environmental diatom study. Professional Paper Belgische Geologische Dienst 241:20-43.

Dixet, S., P. Van Cappellen and J. van Bennekm 2001. Processes controlling solubility of biogenic silica and pore water build up of silicic acid in marine sediments. Marine Chemistry 73:333-352.

Dong, X., H. Bennion, R.W. Battarbee, X. Yang, H. Yang and E. Liu 2008. Tracking eutrophication in Taihu Lake using the diatom record: Potential and problems. Journal of Paleolimnology 40:413-429.

Eronen, M., T. Kankainen and M. Tsukada 1987. Late Holocene sea-level record in a core from the Puget Lowland, Washington. Quaternary Research 27:147-159.

Fink, D., M. Hotchkis, Q. Hua, G. Jacobsen, A.M. Smith, U. Zoppi, D. Child, C. Mifsud, H. van der Gaast, A. Williams and M. Williams 2004. The ANTARES AMS Facility at ANSTO. Nuclear Instruments and Methods B 223-224:109-115.

Foged, N. 1978. Diatoms In Eastern Australia. Bibliotheca Phycologica 47. Stuttgart: J. Cramer.

Finkelstein, S.A. and A.M. Davis 2005. Paleoenvironmental records of water level and climatic changes from the middle to late Holocene at a Lake Erie coastal wetland, Ontario, Canada. Quaternary Research 65:33-43.

Freund, H., G. Gerdes, H. Steif, O. Dellwig and F. Watermann 2004. The indicative meaning of diatoms, pollen and botanical macro fossils for the reconstruction of palaeoenvironments and sea-level fluctuations along the coast of Lower Saxony; Germany. Quaternary International 112:71-87. 
Gaiser, E. and K. Ruhland 2010. Diatoms as indicators of environmental change in wetlands and Peatlands. In J.P. Smol and F. Stoermer (eds) The Diatoms: Applications for the Environmental and Earth Sciences. Second edition. Cambridge, UK: Cambridge University Press.

Gell P.A., J.A. Sonneman, M.A. Reid, M.A. Illman and A.J. Sincock 1999. An illustrated key to the common diatom genera from southern Australia. Cooperative Research Centre for Freshwater Ecology - Identification Guide No. 26.

Geomarine 1997. Belongil Creek: Estuarine Processes Study. Final Report, December 1996. Report prepared for the Belongil Creek Estuarine Management Committee.

Gignac, L.D., D.H. Vitt, S.C. Zoltai and S.E. Bayley 1991. Bryophyte response surfaces along climatic, chemical, and physical gradients in peatlands of western Canada. Nova Hedwigia 53:27-71.

Godwin, H. 1940. Pollen analysis and forest history of England and Wales. New Phytologist 39:370-400.

Gorham, E. and L. Rochefort 2003. Peatland Restoration: A brief assessment with special reference to Sphagnum bogs. Wetlands Ecology and Management 11:109-119.

Harris, P.T., A.D. Heap, S.M. Bryce, R. Porter-Smith, D.A. Ryan and D.T. Heggie 2002. Classification of Australian clastic coastal depositional environments based upon a quantitative analysis of wave, tidal and river power. Journal of Sedimentary Research 72:858-870.

Jasinski, J.P.P., B.G. Barner, A.A. Andreev, R. Aravena, S.E. Gilbert, B.A. Zeeb, J.P. Smol and A.A. Velichko 1998. Holocene environmental history of a peatland in the Lena River valley, Siberia. Canadian Journal of Earth Sciences 35:637-648.

Juggins, S. 2004. C2 Data Analysis. Version 1.4 Beta (build 3.2). University of Newcastle, UK.

Kealhofer, L. and D. Penny 1998. A combined pollen and phytolith record for fourteen thousand years of vegetation change in northeastern Thailand. Review of Palaeobotany and Palynology 103:83-93.

Korhola, A. 1990. Paleolimnology and hydroseral development of the Kotasuo bog, southern Finland, with special reference to the Cladocera. Annales Academie Scientiarum Fennicae A III 155, 40pp.

Kumano, S., M. Ihira, Y. Maeda, M. Yamauchi, E. Matsumoto and L. Matsuda 1990. Holocene sedimentary history of some coastal plains in Hokkaiso, Japan. IV. Diatom assemblages in the sediments from Kushiro Moor (2). Ecological Restoration 5:221-235.

Langdon, P.G., K.E. Barber and P.D.M. Hughes 2003. A 7500-year peat-based palaeoclimatic reconstruction and evidence for an 1100-year cyclicity in bog surface wetness from Temple Hill Moss, Pentland Hills, southeast Scotland. Quaternary Science Reviews 22:259-274.

Larcombe, P., R.M. Carter, J. Dye, M.K. Gagan and D.P. Johnson 1995. New evidence for episodic postglacial sea-level rise, central great-barrier-reef, Australia. Marine Geology 127:1-44.

Lewin, J. 1960. The dissolution of silica from diatom walls. Geochima et Geochimica Acta 21:182-198.

Lewis, R.O. 1981. Use of Opal Phytoliths in Palaeoenvironmental Reconstruction. Journal of Ethnobiology 1:175-181.

Lewis, S. E., R.A. Wust, J.M. Webster and G.A. Shields 2008. Mid-late Holocene sea-level variability in eastern Australia. Terra Nova 20:74-81.

McCormac, F.G., A.G. Hogg, P.G. Blackwell, C.E. Buck, T.F.G. Higham and P.J. Reimer 2004. SHCal04 Southern Hemisphere Calibration 0 - 11.0 cal kyr BP. Radiocarbon 46:1087-1092.

McGrath, R. and W.E. Boyd 1998. Holocene vegetation history of Bundjalung National Park and Bungawalbin Creek, north eastern New South Wales. Australian Geographer 29:205-221. 
Myers-Smith, I.H., J.W. Harden, M. Wilmking, C.C. Fuller, A.D. McGuire and F.S. Chapin III 2008. Wetland succession in a permafrost collapse: interactions between fire and thermokarst. Biogeosciences 5:1273-1286.

O'Connell, M.J. 2003. Detecting, measuring and reversing changes to wetlands. Wetlands Ecology and Management 11: 397- 401.

Parr, J.F. 2002. A comparison of heavy liquid flotation and microwave digestion techniques for the extraction of fossil phytoliths from sediments. Review of Palaeobotany and Palynology 120:315-336.

Parr, J.F. 2003. A study of Palaeo-Landscapes in the Numundo region of West New Britain, Papua New Guinea, as indicated by Fossil Phytolith Analysis. Unpublished PhD Thesis. Lismore: Southern Cross University.

Parr, J.F. 2004. Morphometric and visual fossil phytolith identification using a regionally specific digital database. Phytolitharian 16(2):2-10.

Parr, J.F. and L.A. Sullivan 2005. Soil carbon sequestration in Phytoliths. Soil Biology and Biochemistry 37(1):117-124.

Parr, J.F., V. Dolic, G. Lancaster and W.E. Boyd 2001. A microwave digestion method for the extraction of phytoliths from herbarium specimens. Review of Palaeobotany and Palynology $116: 203-212$.

Parr, J.F., K.H. Taffs and C.M. Lane 2004. A microwave digestion technique for the extraction of fossil diatoms from coastal lake and swamp sediments. Journal of Paleolimnology 31(3):383-390.

Pienitz, R. 2001. Analyse des microrestes végétaux : diatomées. In S. Payette and L. Rochefort (eds)Écologie des tourbières du Québec-Labrador, pp311-326. Québec: Les Presses de l'Université Laval.

Piperno, D.R. 1988. Phytolith Analysis: An Archaeological and Geological Perspective. London: Academic Press.

Reimer, P.J., M.G.L. Baillie, E. Bard, A. Bayliss, J.W. Beck, C.J.H. Bertrand, P.G. Blackwell, C.E. Buck, G.S. Burr, K.B. Cutler, P.E. Damon, R.L. Edwards, R.G. Fairbanks, M. Friedrich, T.P . Guilderson, A.G. Hogg, K.A. Hughen, B. Kromer, G. McCormac, S. Manning, C.B. Ramsey, R.W. Reimer, S. Remmele, J. R. Southon, M. Stuiver, S. Talamo, F.W. Taylor, J. van der Plicht and C.E. Weyhenmeyer 2004. Intcal04 terrestrial radiocarbon age calibration, 0-26 cal kyr BP. Radiocarbon 46:1029-1058.

Rochefort, L., F. Quinty, S. Campeau, K. Johnson and T. Malterer 2003. North American approach to the restoration of Sphagnum dominated Peatlands. Wetlands Ecology and Management 11(1-2):3-20.

Rühland, K., J.P. Smol, J.P.P. Jasinski and B. Warner 2000. Response of diatoms and other siliceous indicators to the developmental history of a peatland in the Tiksi Forest, Siberia, Russia. Arctic, Antarctic and Alpine Research 32:167-178.

Rühland, K., N.R. Phadtare, R.K. Pant, S.J. Sangode and J.P. Smol 2006. Accelerated melting of Himalayan snow and ice triggers pronounced changes in a valley peatland from northern India. Geophysical Research Letters 33 (15):L15709.

Ryves, D., R. Battarbee and S. Fritz 2009. The dilemma of disappearing diatoms: Incorporating diatom dissolution data into palaeoenvironmental modelling and reconstruction. Quaternary Science Reviews 28:120-136.

Sterrenburg, F., R. Gordon, M.A. Tiffany and S.S. Nagy 2007. Diatoms: living in a constructal environment. In J. Seckbach (ed) Algae and Cyanobacteria in extreme environments, pp143172. Dordrecht, Netherlands: Springer Press.

Stoermer, F. and J.P. Smol 1999. The Diatoms: Applications for the Environmental and Earth Sciences. Cambridge, UK: Cambridge University Press.

Stuiver, M. and P.J. Reimer 1993. Extended C14 database and revised CALIB 3.0 C14 age calibration program. Radiocarbon 35:215-230. 
Sullivan, L.A., R.T. Bush and D.M. McConchie 2000. A modified chromium-reducible sulfur method for reduced inorganic sulfur: Optimum reaction time for acid sulfate soil. Australian Journal of Soil Research 38:729-734.

Taffs, K.H., J.F. Parr and K.G.E. Bolton 2006. Using Palaeobotany to resolve ecological disasters in East Australian peatlands. Ecological Management and Restoration 7(2):132-135.

Taffs, K.H., L.J. Farago, H. Heijnis and G. Jacobsen 2008. A diatom-based holocene record of human impact from a coastal environment: Tuckean Swamp, eastern Australia. Journal of Paleolimnology 39:71-82.

Vasander, H., A.S. Tuittila and E. Lode 2003. Status and restoration of Peatlands in northern Europe. Wetlands Ecology and Management 11(1-2):51-63.

von Post, L. 1916. Om Skogstradspollen i sydsvendka torfmosselagerfoljder (foredragsreferat). Geologiska Föreningen i Stockholm Förhandlinga 38:384-394.

Vyverman, W., R. Vyverman, D. Hodgson and P. Tyler 1995. Diatoms from Tasmanian mountain lakes: a reference data-set (TASDIAT) for environmental reconstruction and autoecological study. Bibliotheca Diatolologica, Band 33. Berlin: J. Cramer.

Wein, R.W., M.P. Burzynski, B.A. Sreenivasa and K. Tolonen 1987. Bog profile evidence of fire and vegetation dynamics since 3000 years BP in the Acadian Forest. Canadian Journal of Botany 65:1180-1186.

Whinam, J., G.S. Hope, B.R. Clarkson, B.P. Buxton, P.A. Alspach and P. Ada 2003. Sphagnum in peatlands of Australasia: their distribution, utilisation and management. Wetlands Ecology and Management 11(1-2):37-49. 